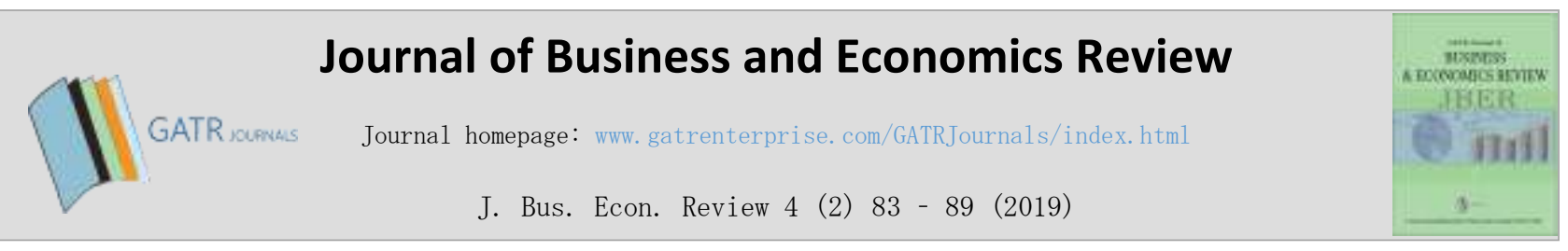

\title{
Factors Affecting the Intention of Millennial Workers in Indonesia to Leave
}

\author{
Nurul Komari ${ }^{1}$, Sulistiowati ${ }^{2}$ \\ ${ }^{1,2}$ Faculty of Economics and Business, Universitas Tanjungpura, Jl. Prof. Dr. Hadari Nawawi, 78124, Pontianak, Indonesia
}

\begin{abstract}
Objective - This study examines the effect of mediating work pressure on the relationship between the quality of work life and the desire to leave of millennial employees.

Methodology/Technique - The highest portion of the workforce in Indonesia in 2016 is the millennial generation, which comprises around 62.5 million people. Millennials possess different attitudes, characteristics and skills than the Baby Boomer generation. Millennial employees are perceived to look for the value of work to improve the quality of work life rather than financial benefits. Organizations must understand the character of millennial employees to gain the best talents.

Findings - The findings of the study show that quality of work life has a negative and significant effect on work stress. Meanwhile, work stress has a positive and significant effect on intention to leave. Finally, the quality of work life has a negative and significant effect on intention to leave.
\end{abstract}

Research Limitations / Implications - This study concludes that work stress mediates the relationship between the quality of work life and intention to leave. This study concludes that quality of work life is very important for low work stress and reducing the intention to leave among millennial employees.

Novelty - These findings expand upon existing research related to the quality of work life, work stress and turnover intention and provides recommendations for organizations to retain millennial employees.

Type of Paper: Empirical.

Keywords: Millennial; Quality of Work Life; Work Stress; Intention to Leave.

Reference to this paper should be made as follows: Komari, N.; Sulistiowati. (2019). Factors Affecting the Intention of Millennial Workers in Indonesia to Leave, J. Bus. Econ. Review, 4 (2): 83 - 89

https://doi.org/10.35609/jber.2019.4.2(2)

JEL Classification: J60, J61, J69.

\section{Introduction}

Labor in Indonesia is experiencing a period of change. Based on data of the Central Bureau of Statistics (Biro Pusat Statistik/BPS) 2016, the number of employees in Indonesia is approximately 160 million of which approximately 62.5 million are born in millennial era.

\footnotetext{
* Paper Info: Revised: March 15, 2019

Accepted: June 16, 2019

* Corresponding author: Nurul Komari

E-mail: nurul.komari@ekonomi.untan.ac.id
} 
Affiliation: Faculty of Economics and Business, Universitas Tanjungpura, Indonesia

Millennial employees have changed the atmosphere of the workplace. One such significant change is that millennial employees have different attitudes, skills and characteristics to the Baby Boomer generation. The consequence of this is that organization must provide a different quality of work life to suit their characteristics in order to avoid high turnover rates. However, a survey of employee engagement among millennials conducted by Dale Carnegie (2016) found that, in Indonesia, 66\% of employees are only partly (partially-engaged) involved and 9\% refused to get involved. Obviously, this will have a negative impact since this generation are at risk of disengaging and ultimately leaving the company. Frian and Mulyani (2018) state that the rate of turnover among millennial employees in Indonesia is high.

A survey conducted by Fidelity Investments (2016) indicates that millennial employees are happy at work, however $41 \%$ of them planned to start a new job within two years and $49 \%$ actively sought a new job. A study by Meister (2012) found that out of 1,339 respondents, $91 \%$ of millennial employees survived working in one workplace for no more than three years, $34 \%$ for one year or less and $53 \%$ for one to two years (Daming \& Xiaoyun, 2010). Hence, it is important to further investigate the factors that influence the intention of millennial employees to leave. Therefore, the objective of this study is to examine the effect of the quality of work life and work stress on employee intention to leave within an insurance company in Indonesia.

\section{Literature Review}

\subsection{Millennial Generation}

The millennial generation is the generation born between 1980 and 1995. The millennial generation has a unique character as they were born and grew during the technology boom. They are living in the era of the evolution of information and communication technology. The millennial employees appreciate freedom and work-life balance in their job (Twenge, 2010). Saragih, Widodo and Prasetyo (2016) found that millennial employees need good benefits, good work location, career opportunities and the chance to grow (Baldonado \& Spangenburg, 2009). In addition, they have also been identified as hard workers and individuals who love life value. They also have confidence, team-oriented attitudes, are focused on achievement, always do the best and strive to achieve something higher (Howe \& Straus, 2009). Therefore, organizations must understand these characteristics to gain the best talent of a millennial employee. Organizations that are able to deliver a quality work life to suit the characteristics of the millennial workforce will be able to reduce their turnover rate, and will have an impact on the value of the company.

\subsection{Quality of Work Life}

Schermehorn, Hunt and Osborn (2005) define the quality of work life as the overall quality of human experiences in the workplace. In line with Schermehorn et. al. (2005) found that millennial employees prefer looking for the value of work to improve the quality of working life rather than financial benefits. They are willing to accept less salary for a career and work life balance. However, Srinivasan (2012) states that the fairness of payment is a dominant factor affecting motivation among millennial employees. In addition, Smith (2010) states that flexibility, ethical decisions, long-term satisfaction, quality of corporate culture and performance are more important for millennial employees. A survey by Dale Carnegie (2016) found that millennial employees are more sensitive to their work environment and do not like routine work. Previous studies (Ahmad, 2013; Bragard, Dupuis, Razavi, Reynaert, \& Etienne, 2012; Mosadeghrad, 2013) suggest that the quality of work life is intended to create the best work environment where employees can cooperate with each other. This may increase productivity and lead to a highly competitive company. A good quality of work life is indicated by the stability of the employee's work schedule and emotions. Several studies indicate that there is a negative relationship between quality of work life and intention to leave (Shahzad, Rehman, 
Shad, Gul, \& Khan, 2011; Mosadeghrad, 2013; Korunka, Hoonakker, \& Carayon, 2008). Almaki (2012) posits that work context and design are the most important dimensions of quality of work life having an effect on one's intention to leave.

\subsection{Work Stress}

Mosadeghrad, Ferlie and Rosenberg (2011) comment that work pressure is caused by unbalanced work, lack of payment, management support, job security, and promotion opportunities. Kasraie, Sheler, Mohammad and Abolfazl (2014) suggest there are four main reasons for organizations to focus on. These are: employee health, financial impact of health services, organizational effectiveness, and legal compliance with worker compensation programs. Veloutsou and Panigyrakis (2004) report that work pressure has implications for individuals as well as organizations. Pisheh's study (2012) suggests that employee work pressure can be reduced and easily managed by creating a win-win program. To reduce work pressure, organizations need to manage quality of work life to encourage motivation, and provide incentives such as employee travel (Yin-Fah, Foon, Chee-Leong, \& Osman, 2010). Gayathiri and Ramakrishnan (2013), Pisheh (2012) and Kasraie et. al. (2014) have found that quality of work life has a significant and negative effect on work stress.

\subsection{Intention to Leave}

Prior studies have argued that the main reasons millennial employees leave their job include inadequate compensation, alternative opportunities, employee involvement, and development (Frian \& Mulyani, 2018). Meanwhile, Yin Fah (2010) found that ethnicity, gender and lack of career development (Tummers, Groeneveld, \& Marcel, 2013; Coomber \& Barriball, 2007), role conflict, role overload, and work-family conflict (Hang-yue et. al., 2005) all affect turnover rates. Pisheh (2012) found that work stress has a significant effect on intention to leave. Meanwhile, Liyanage, Madhumini and Galhena (2014) and Veloutsou and Panigyrakis (2004) argue that there is a positive but not significant correlation between work stress and the intention to leave. Qureshi, Iftikhar, Abbas, Hassan, Khan and Zaman (2013) claim that good working conditions will reduce intentions to leave. Further Veloutsou and Panigyrakis (2004) argue that satisfaction with things and achievement of results are strongly related to the desire to leave. However, satisfaction with opportunities for growth and promotion and working conditions is actually weak in affecting intention to leave.

\subsection{Equity Theory}

Equity theory is a social comparison concept, whereby employees assess their own results compared to other employees (Carrell \& Dittrich, 1978). This theory assumes that humans always crave justice for every behavior carried out. Justice is the driving force that motivates employees to work (Redmond, 2010). Equity theory has been used in management studies to explain employee reactions to company policies (Azar \& Darvishi, 2011). Gogia (2010) states that this theory, when applied to the workplace, is primarily focused on the problem of employee compensation.

Based on the literature, the research hypotheses in this study are as follows:

Hypothesis 1: quality of work life has a significant effect on work stress.

Hypothesis 2: work stress has a significant effect on intention to leave.

Hypothesis 3: quality of work life has a significant effect on intention to leave.

Hypothesis 4: work stress mediates the relationship between quality of work life and intention to leave. 


\section{Research Methodology}

This study proposes three variables in the conceptual framework including: quality of work life, work stress and intention to leave. The independent variable is quality of work life, whilst the dependent variable is intention to leave. Work stress is used as the intervening variable. Quality of work life was measured by six indicators adapted from Schemerhorn et. al. (2005). In addition, the five indicators were used to assess work stress which were adapted from Roberts, James, Richard, Lapidus and Lawrence (1997). The dependent variables of intention to leave was measured using five indicators adapted from Xiong and Francesco (2000). A total of 100 financial consultants in an insurance company were selected as the respondents. A list of questions in the questionnaire is given to the respondents to be answered. The respondents were given a choice of answer using a Likert Scale method which consisted of 5 scores namely: score 1, 2, 3, 4 and 5 equal to strongly disagree, do not agree, quite agree, agree, and strongly agree, respectively. The data was analysed using Path Analysis.

\section{Results}

The results of this study report that the working period of the respondents was 3 years at most (5\%), $47 \%$ worked for less 1 year and the rest stayed for between $1-2$ years $(48 \%)$. Most of the respondents graduated from high school (72\%) and they are aged primarily between 26-35 years old (60\%). 61\% of the respondents were married. The respondents were relatively balanced between men and women. The reliability tests show a correlation coefficient of each variable which was greater than 0.70 . This means that the indicators can be relied upon to measure the variables (Chin, 1998). The validity indicators were indicated by the coefficient correlation of all of the indicators which should be greater than 0.50 . The results of the data analysis show that the mean scores for quality of work life, work stress and intention to leave were 3.69, 1.76 and 1.75, respectively. This indicates that, on average, the respondents have a high quality of work life, low work stress and low intention to leave.

Table 1. Hypothesis Test Results

\begin{tabular}{|l|l|l|l|l|}
\hline Direction of Causality & Coefficient & t-statistics & Significant & Decision \\
\hline Quality of work life -> Work stress & -0.392 & -4.219 & $0.000^{*}$ & Supported \\
\hline Work stress -> Intention to leave & 0.290 & 3.003 & $0.003^{*}$ & Supported \\
\hline Quality of work life -> Intention to leave & -0.235 & -2.389 & $0.019^{*}$ & Supported \\
\hline $\begin{array}{l}\text { Quality of work life -> Work stress -> } \\
\text { Intention to leave }\end{array}$ & 0.091 & 2.527 & $0.026^{*}$ & Supported \\
\hline
\end{tabular}

Notes: Asterisk (*) denotes significant at the 5 percent level

\section{Discussion}

The results of the data analysis found that the affect of the quality of work life on intention to leave was negative and significant. This indicates that a maximum positive perception of quality of work life might weaken one's intention to leave. This means that those employees who have a positive perception of their quality of work life in their insurance institutions are more likely to stay in their job. These findings are consistent with the previous literature (Shahzad et. al., 2011; Mosadeghrad, 2013). Frian and Mulyani (2018) and Srinivasan (2012) state that millennial employees like fair and attractive compensation. Gogia (2010) claims that equity theory is applied to the workplace to deal exclusively with the issue of employee compensation. Millennial employees are also interested in improving their working conditions (Buzza, 2017), 
therefore it is important for companies to create security and work life balance (Veloutsou \& Panigyrakis, 2004).

The results of this research found that the affect of the quality of work life on work stress was negative and significant. These findings indicate that employees who have a positive perception of their quality of work life in their insurance institutions experience decrease levels of work stress. These findings are similar to the findings by Gayathiri and Ramakrishnan (2013) and Pisheh (2012). Millennial employees need a balanced working life, a fun and meaningful work environment and freedom (Twenge, 2010). Millennial employees are also very dependent on the internet and smart phones and are actively involved in social media networks. Technology is therefore a large part of their work (Eisner, 2005; Howe \& Strauss, 2009).

The results of the research show that work stress has a positive influence on intention to leave behaviour. Thus, as shown in previous studies, it can be said that work stress reinforces intention to leave behaviour among insurance professionals. The results of the present study are consistent with the equity theory (Carrell \& Dittrich, 1978). The work stress construct has a positive and significant mediating effect on the relationship between quality of work life and intention to leave behaviour. These findings indicate that the lower one's work stress is, the lower the intention to leave behavior is. There are a number of studies that have demonstrated a positive relationship between work stress and intention to leave behaviour (Ahmad, 2013; Qureshi et. al., 2013; Hang-yue et. al., 2005; Yin-Fah et. al., 2010; Lin, Qiu-Hong, Jiang, Chao-Qiang, \& Lam, 2013; Noor \& Nazia, 2008). Work pressure can be overcome by the company by providing employee travel incentives (Yin-Fah et. al., 2010) and entertainment (Buzza (2017). The company can also provide workplace flexibility to facilitate the millennial dynamic, which is a free and happy lifestyle. Providing a work environment that is consistent with the characteristics of millennial employees will increase their work productivity.

\section{Conclusion}

The findings in the study show that quality of work life has a negative and significant effect on work stress. Meanwhile work stress has a positive and significant effect on intention to leave. Finally, quality of work life has a negative and significant effect on intention to leave. Work stress mediates the relationship between quality of work life and intention to leave. This study concludes that quality of work life is very important to ensure low levels of work stress and intention to leave among millennial employees. This research however has some limitations. The sample population is limited to one province, so the findings cannot be generalized for insurance companies across Indonesia. Future research with a much larger sample size conducted across many provinces should be conducted to complement the results of this research. Furthermore, further research should explore various factors such as ethnicity, race, and culture to observe whether these factors moderate the relationship between quality of work life and turnover intention. The findings of this research expands on existing research related to quality of work life, work stress and turnover intention and provides recommendations for organizations to enable them to retain their millennial employees.

\section{References}

Ahmad, S. (2013). Paradigms of Quality of Work Life. Journal of Human Values, 19(1), 73-82. https://doi.org/10.1177/0971685812470345

Almaki, M. J. (2012). Quality of Work Life and Turnover Intention in Primary Healthcare Organizations: AcrossSectional Study of Registered Nurses in Saudi Arabia. Thesis. Queensland University of Technology. doi: 10.1186/1478-4491-10-30

Azar, A. and Darvishi, Z. A. (2011). Development and Validation of a Measure of Justice Perception in the Frame of Fairness Theory-Fuzzy Approach. Expert Systems with Applications, 38, 7364-7372. https://doi.org/10.1016/j.eswa.2010.12.090 
Baldonado, A. M. and Spangenburg, J. (2009). Leadership and the Future: Gen Y Workers and Two-factor Theory. The Journal of American Academy of Business Cambridge, 15(1), 99 -103. http://eprints.utar.edu.my/704/1/MBA-20120901165-1.pdf

Bragard, I., Dupuis, G., Razavi, D., Reynaert, C. and Etienne, A.-M. (2012). Quality of Work Life in Doctors Working With Cancer Patients. Occupational Medical Journal, 62, 34-40. DOI: 10.1093/occmed/kqr149

Buzza, J. S. (2017). Are you living to work or working to live? What millennials want in the workplace. Journal of Human Resources, 5(2), 15-20. DOI: 10.15640/jhrmls.v5n2a3

Dale Carnegie. (2016). 50 Employee engagement idea and tips. Access at https://amelio.co/References/Dale Carnegie EE.pdf

Carrell, M. R., \& Dittrich, J. E. (1978). Equity Theory: The Recent Literature, Methodological Considerations, and New Directions. The Academy of Management Review, 3 (2), 202-210. https://doi.org/10.5465/amr.1978.4294844

Chin, W. W. (1998). The partial least squares approach to structural equation modelling. In G. A. Marcoulides (Ed.), Modern methods for business research, 295-336. Mahwah, NJ: Lawrence Erlbaum Associates, Inc. https://psycnet.apa.org/record/1998-07269-010

Coomber, B., \& Barriball K. L. (2007). Impact of job satisfaction components on intent to leave and turnover for hospital-based nurses: a review of the research literature. International Journal of Nursing Studies, 44 (2), $297-314$. DOI: 10.1016/j.ijnurstu.2006.02.004

Deloitte Touche Tohmatsu (Firm). (2018). Deloitte Millennial Survey: millennials disappointed in business, unprepared for Industry $4.0 \mathrm{https} / / / \mathrm{www}$. voced.edu.au/content/ngv:80961

Daming, Z., \& Xiaoyun, S. (2010). Research on" job hopping" by migrant workers from the countryside: a second study on turnover among migrant workers employed by businesses. Chinese Sociology \& Anthropology, 43(2), 51-69.

Eisner, S. P. (2005). Managing Generation Y. Society for Advancement Management Journal, 70 (4), 4-15.

Fidelity investment. (2016). Evaluate a $\quad$ job offer study https://www.fidelity.com/bin\%20public/060_www_fidelity_com\%2\%20Fdocuments/\%20fidelity-job-offer-factsheet.pdf

Frian., \& Mulyani. (2018). Millenials employee turnover intention in Indonesia. Innovative Issues and Approaches in Social Sciences, 11(3), 90-111. http://dx.doi.org/10.12959/issn.1855-0541.IIASS-2018-no3-art5

Gayathiri, R., \& Ramakrishnan L. (2013). Quality of work life-linkage with job satisfaction and performance. International Journal of Business and Management Invention, 2 (1), $1-8$. https://pdfs.semanticscholar.org/5ab4/1a9b14b5e3c791ae5d6da4dba9be3cfef9e5.pdf

Gogia, P. (2010). Equity theory of motivation. Retrieved from http://www.businessihub.com/equity-theoryofmotivation/

Hang-yue, N., Foley, S., \& Loi, R. (2005). Work role stressors and turnover clergy in Hong Kong. International Journal of Human Resource Management. 6 (11), 2133-2146. http://dx.doi.org/10.1080/09585190500315141

Howe, N., \& Strauss, W. (2009). Millennials rising:The next great generation. Vintage. Retrievedfrom http://en.wikipedia.org/wiki/Millennials.

Kasraie, S., Sheler, P., Mohammad, H., \& Abolfazl, G. Z. (2014). The relationship between quality of work life, job stress, job satisfaction and citizenship behavior in Oshnaviyeh Hospital's Staff. Patient Safety and Quality Improvement Journal, 2 (2), 77-81. https://doaj.org/article/4b69d57c7a1d473d8c59707e97453579

Korunka, C., Hoonakker, \& Carayon, P. (2008). Quality of Working Life and Turnover Intention in Information Technology Work. Human Factors and Ergonomics in Manufacturing. 18 (4): 408-423. https://doi.org/10.1002/hfm.20099

Lin, Qiu-Hong., Jiang, Chao-Qiang., \& Lam, T. H. (2013). The relationship between occupational stress, burnout, and turnover intention among managerial staff from a Sino-Japanese joint venture in Guangzhou, China. Journal of Occupational Health, 55, 458-467. https://doi.org/10.1539/joh.12-0287-OA

Liyanage, D. M., Madhumini, A. M., \& Galhena, B. L. (2014). Is occupational stress a good predictor of turnover intention? Evidence from a leading garment manufacturer in Sri Lanka. Proceedings of the 3rd International Conference on Management and Economics, 285-292.

Meister, J. (2012). Job hopping is the'new normal'for millennials: Three ways to prevent a human resource nightmare. Retrieved from http://www.forbes.com.

Mosadeghrad, A. M., Ferlie, E., \& Rosenberg, D. (2011). A study of relationship between job stress, quality of working life and turnover intention among hospital employees. Health Services Management Research, 24, 170-181. DOI: 10.1258/hsmr.2011.011009 
Mosadeghrad, M. A. (2013). Quality of working life and turnover intentions: implications for nursing management. International Journal of Research in Nursing, 4 (2), 47-54. DOI: 10.3844/ijrnsp.2013.47.54

Noor, S \& Nazia, M. (2008). Examining the Relationship between Work Life Conflict, Stress and Turnover Intentions among Marketing Executives in Pakistan. International Journal of Business and Management, 3(11). DOI: 10.5539/ijbm.v3n11p93

Pisheh, M. H. M. (2012). Quality of work life and job stress among Iran Public employees, 6 (28), 8296-8308. https://doi.org/10.5897/AJBM11.1091

Qureshi, M, I., Iftikhar, M., Abbas. Hassan, U., Khan, K., \& Zaman. (2013). Relationship between job stress, workload, environment and employees turnover intentions: what we know, what should we know. World Applied Sciences Journal, 23 (6), 764-770.

Redmond, B. (2010). Equity theory: Is what I get for my work fair compared to others? Work Attitudes and Motivation. The Pennsylvania State University World Campus.

Roberts. James. Richard. Lapidus. \& Lawrence, C. B. (1997). Sales people and stress: the moderating role of focus of control on work stressors and felt stress. Journal of marketing theory and practice, 93-100. https://doi.org/10.1080/10696679.1997.11501773

Saragih, E. H., Widodo, A., \& Prasetyo, B. (2016). Big city millenial workers in Indonesia and factors affecting their commitment to the organisation. Pertanika Journal of Social Science and Humanities, 24, 47-58 https://core.ac.uk/download/pdf/153832282.pdf

Schemerhorn, J. R., Hunt, J. G., \& Osborn, R. N. (2005). Organisasional Behaviour an Asia-Pacific Perspective. Jacaranda Wiley: Australia.

Shahzad, K., Rehman, U., Shad, I., Gul, A., \& Khan, A. M. (2011). Work-life policies and job stress as determinants of turnover intentions of customer service representatives in Pakistan. European Journal of Social Sciences, 19 (3), 403 411.

Smith, T. K. (2010). Work life balance perspectives of Marketing Professionals in generation Y. Services Marketing Quarterly, 31(4), 434-447. https://doi.org/10.1080/15332969.2010.510724

Srinivasan, V. (2012). Multi generations in the workforce: Building collaboration. IIMB Management Review, 24(1), 48-66. https://doi.org/10.1016/j.iimb.2012.01.004

Tummers, L. G., Groeneveld, S. M., \& Marcel L. M. (2013). Why do nurses intend to leave their organization? A largescale.analysis in long-term care. Journal of Advanced Nursing. DOI: 10.1111/jan.12249

Twenge, J. M. (2010): A review of the empirical evidence on generational differences in work attitudes. Journal of Business and Psychology, 25 (2), 201-210. http://dx.doi.org/10.1007/s10869-010-9165-6

Veloutsou, C. A., \& Panigyrakis, G. G. (2004). Consumers brand managers, job stress, job satisfaction, perceived performance and intention to leave. Journal of Marketing Management, 20, 105-131.

Xiong, Z, C., \& Francesco, M, A. (2000). Organizational, commitment and turnover intention in China do culturer differences matter. Human Relation, 56 (6), 869-887.

Yin-Fah, B. C., Foon, Y. S., Chee-Leong, L., \& Osman, S. (2010). An Exploratory study on turnover intention among private sector employees. International Journal of Business and Management, 5 (8), 57-64. DOI:10.5539/ijbm.v5n8p57 